\title{
臨床で重要な薬物相互作用情報とは
}

\section{The Imformation on Clinical Important Drug Interactions}

\author{
小林 真一 \\ (聖マリアンナ医科大学薬理学)
}

\author{
Shinichi KOBAYASHI \\ Professor, Department of Pharmacology, St. Marianna University School of Medicine, Kanagawa
}

\begin{abstract}
Summary: Information concerning drug interactions is essential for physicians and patients when attempting to limit the number of serious adverse events. This information, however, is generally the result of research initiated by pharmaceutical companies and regulatory authorities, and as such not aimed at the needs of either physician or patient. This article carefully assesses these needs and intends to provide guidance in order to improve the current situation. To this end a number of practical examples of drug interaction are re-evaluated in terms of their informative utility.
\end{abstract}

\section{Key words: Clinical imformation, Drug interactions, Adverse events, Physicians}

\section{はじめに}

臨床的に薬物相互作用を考える場合には二つの側面か ら考える必要がある. 一つは患者にとって有益な薬物相 互作用であり，一般的に薬物併用療法といわれている. 他方，患者にとって有害な薬物相互作用も存在し，この ような場合に臨床医はをの有害な相互作用をなくすため の努力と同時に患者の原疾患をも治療せねばならず非常 に悩むことが多い。

我が国の現状に抢ける薬物相互作用情報はまだまだ臨 床医にとって臨床的にすぐ使える情報, 臨床医の疑問に 答えられる情報になっていないものも多く，その情報が 臨床現場で十分生かされていないのが現状である.

そこでまずはじめに薬物相互作用の問題点について考 え，次に現在すでに報告されている薬物相互作用情報を 参考文献をもとに「臨床医にとって有益な相互作用情報 とは」について考えることとする.

\section{医療現場での薬物相互作用}

一般に臨床医が薬物治療を開始する時は，そのすべて が原疾患の病因に則って薬物を選択するわけではなく， 多くは患者の示す多岐に渡る症状に対して薬物を選択す る場合が多い，この上うな場合，複数の薬物が併用投与 されることになる．また患者個人個人によって症状も多 少異なり併用される薬物も個々の患者で異なってくる. このように実際に薬物治療を行う場合, 症状が多い疾患
また高齢患者のように加齢とともに症状の多くなる患者 では併用される薬物の数は当然多くなり，このことは有 害な薬物相互作用を茩起する可能性も増加することを示 唆している.

\section{1. 臨床上有益な薬物相互作用}

一般の人々には「薬物相互作用」という言葉は何かネ ガティブなイメージでとらえられる傾向にある。しか し，先にも述べたように薬物相互作用は臨床的に有益な 場合と有害な場合がある．患者側からすれば治療とは有 益なものであり有益な薬物併用療法は当然のこととして あまり意識されていないことが多い。逆に有害な薬物相 互作用は患者にとって予期せぬことであり，本来治療に よって軽減するはずの症状が悪化したり，精神的・肉体 的ダメージは予想外であり，そのため「薬物相互作用」 は望まないこと, 悪いこととして理解されやすい。

実際の医療現場で臨床医はある薬物の有害作用を抑え るために他の薬物を併用投与することがある．たとえば 抗癌薬を投与した癌患者に対しその副作用である吐気を 抑えるために制吐薬を併用投与したり，非ステロイド系 抗炎症薬と健胃消化薬・制酸薬の併用投与などの場合で ある. また局所麻酔薬にエピネフィリンを加えたり，複 数の抗菌薬, 抗癌薬を同時に併用することなどは相互作 用による作用増強をねらっている.

以上のような併用投与は患者にとっては有益な薬物相 互作用を期待しているのである.

聖マリアンナ医科大学薬理学 テ216-8511 川崎市宮前区菅生 2-16-1 


\section{2. 臨床上有害な薬物相互作用}

抗ウイルス薬ソリブジンと抗癌薬 5-FU の薬物相互 作用は大きな社会問題になで発展した. 抗癌薬 $5 \mathrm{FU}$ を 服用していた患者が癌の進行とともに帯状疱疹になり抗 ウイルス薬が必要となり,ソリブジンを服用し，ソリブ ジン発売後 40 日以内に 18 人が亡くなった。これは $5 \mathrm{FU}$ を代謝するジヒドロピリミジン脱水素酵素がソリ ブジンの代謝物で阻害されためである ${ }^{1,2)}$ ：この結果, 我が国も含め世界中の医療現場からソリブジンが回収さ れた.しかし，このソリブジンと $5 \mathrm{FU}$ の相互作用につ いては, 我が国のように癌患者が病名告知されておら ず，また自分の服用している薬物を正確に把握していな い状況では完全な防止は難かしいと思われる.しかしこ の薬物相互作用の場合, 臨床医は当然ドクターレターな どで事前に知らされていたにも関わらず，このような不 幸が生じてしまったところに問題があり，情報開示の方 法, また臨床医のそれらに対する教育・意識改革が必要 である・

一般に臨床医は重篤な(「重篤」とは生命に関わるほど 重症なものの意味)薬物相互作用が起こる可能性のある 場合はその可能性のある薬物の投与を中止するし，また その相互作用が投与量に相関していれば投与量を調節す る.さらにまた投与法を再検討することも考える。もち ろん臨床的に最良の解決方法は原疾患を治療しうる同様 の薬効を持ち相互作用のない他の薬物があることであ る.

臨床医が薬物を投与する場合, 又は薬物相互作用が起 こる可能性が示唆される場合, 本当に得たい情報とは有 害な薬物相互作用の「発生頻度」であり, 有害作用を 「予測するための具体的な方法」である．臨床症状を子 エックすれば予測がつくのか, 臨床検査で頻回にチェッ クすればよいのか, また特異的な検査項目はあるのか, さらに薬物血中濃度モニタリングで予測できるのかなど の情報である.

そして，もし不幸にして有害作用が発現してしまった 場合, 多くの臨床医はその作用が重症なものか, また生 命に関わる重篤なものなのかを考える. そして，その有 害作用が投与量に相関して起こったものか, 可逆的で投 与を中止したらもとにもどる作用か, 非可逆的なものか など有害作用の質を検討する．さらに臨床医はすべての 症例において原疾患に対する治療法を中止することな く，その有害作用を解消する治療情報を探す.

薬物相互作用の情報が臨床医にとって分りにくいよう な情報の場合, たとえばフェニトインがジゴキシンの血 中濃度を $30 \%$ 減少させるという情報の場合, 臨床医は 患者を前にして「併用をやめるべき」なのか,「どのよ うに投与量を調整すべきか」など, 目の前の個々の患者 に適応できる情報がほしいのである.

\section{薬物相互作用の報告例}

臨床医にとって有用な薬物相互作用の情報を検討する ため,すでに報告されている情報のうち，典型的ないく つかを選んで考察してみる.

\section{1. テルフェナジンとエリスロマイシン}

テルフェナジンは米国では 10 年以上前から市販さ れ，広くアレルギー性鼻炎の治療に使用されてきた．テ ルフェナジンは CYP3A4 で代謝され活性代謝物を生成 するが，このテルフェナジンが重篤な心室性不整脈 torsades de pointes を引き起こすことは以前よりいわれて いた. 1992 年に一つの危険因子としてエリスロマイシ ンが報告され, エリスロマイシンとテルフェナジンの併
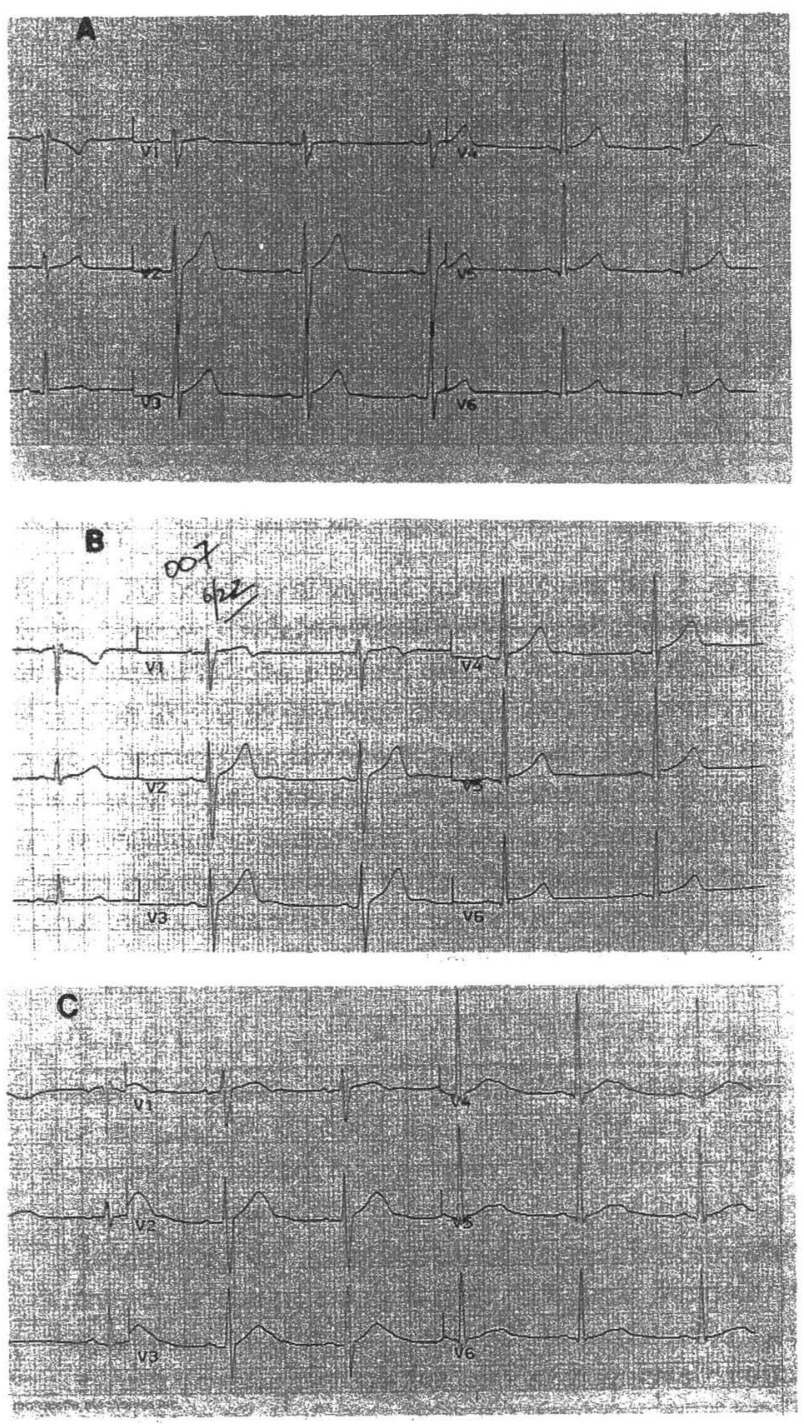

図 1 テルフェナジンとエリスロマイシンの相互作用 : テルフ エナジンの心毒性 ${ }^{3}$

$\mathbf{A}$ : 対照の心電図, B : テルフェナジン単独投与 1 週間 後の心電図, C : テルフェナジンにエリスロマシンを併 用 1 週間後の心電図 
用によってエリスロマイシンが肝蔵のCYP3A4 を阻害 し，テルフェナジンの代謝が阻害されて心電図上で QT 延長が示された $\left(\right.$ 図 $\left.1^{3}\right)$ )。この報告のなかで著者は 「エリスロマイシンとテルフェナジンの併用投与は注意 が必要である」と結論付けている．このような結論の情 報の場合, 果たして臨床医は何に注意すれば良いのであ ろうか？患者を前にして臨床医はこれらの併用を諦ら めるか，をたは血中薬物濃度を測定するように指示する かも知れない。しかし，これらの方法では目の前の患者 の torsades de pointes を予測する事はできない。簡単 で唯一臨床医が予測できる方法は心電図で注意深く QT 間隔を調べることである ${ }^{4)}$. その後, テルフェナジ ンの心毒性を惹起する他の薬物について相互作用の報 告5-7)が多く出され, それらの薬物とテルフェナジンと の併用投与は減少している.

\section{2. バロプロ酸とパニペネム}

最近, カルバペネム系抗生物質のパニペネムと抗てん かん薬バロプロ酸の併用投与によってバロプロ酸の血中 濃度が顕着に減少し, てんかん発作が引き起こされたと いう報告8,9)がある.この相互作用は広く知られていた が，そのメカニズムがバロプロ酸の肝臓でのグルクロン 酸抱合代謝をパニペネムが促進した結果であるとの報 告10)もあり, 屯たパニペネムが腸管細菌を減少させ, その結果, バロプロ酸の腸肝循環を減少させたとの報 告11)もある。このような情報からは臨床医はとりあえ ず併用を諦らめるか, またはバルプロ酸の血中濃度モ二 タリングを行うであろう.

3. リファンピンとオンダンセトロン

最近,フィンランドにおいて制吐薬オンダンセトロン
の薬物動態に対するリファンピンの影響が検討され (図 $2^{12)}$ ), リファンピンによって誘導された CYP3A4 によってオンダンセトロンの代謝が促進され, その結 果, 制吐作用が減少する可能性を示唆した。このような 情報の場合は臨床症状のチェックとともに, もし薬効が 減少されれば併用を諦らめるか, 他の薬物に切り替える 必要があろう。

\section{4. グレープフルーツジュースとシンバスタチン}

昔から食物と薬物の相互作用は知られているが, 近 年, 多くの薬物とグレープフルーツジュースの相互作用 に関する報告が多く, グレープフルーッジュースが CYP3A4 を抑制することは一般的に知られている。 そ の結果, グレープフルーッジュースが消化管の CYP3A4 阻害し, シンバスタチンの初回通過効果を 抑制し, 生体内利用率を増加させたことにより高脂血症 治療薬であり HMG-CoA 還元酵素阻害薬であるシンバ スタチン, シンバスタチン酸の血中濃度を増加させると 報告されている $\left(\right.$ 図 $3^{13)}$ )。最近, グレープフルーツシ ュースに含まれるナリンジニンが in vitro でシンバスタ チンの代謝を阻害したとの報告14)も㐫り,グレープフ ルーツジュースとシンバスタチンの同時摂取は避けるべ きであることが示唆されている15).

\section{5. リファンピン, リファブチンと経口避妊薬}

リファンピン, リファブチンはエチニールエストラダ イオールなどの血中濃度を顕著に減少することが報告さ れている(図 $4^{16)}$ )。この作用はリファンピンの作用の ほうがリファブチンより強力である. その結果, 血中 LH, FSH レベルは併用によって多少上昇する. しかし, これらの值は経口避娃薬を服用する前の值( $\mathrm{LH}: 10.4$,


図 2 リファンピンとオンダンセトロンの相互作用 : オンダンセトロンの血中濃度推移 12 ) リファンピン $600 \mathrm{mg}$ またはプラセボを 5 日間投与後オンダンセトロン $8 \mathrm{mg}$ 経口投与(左図), 静脈投与(右図)後の 血中濃度. 白丸 ; プラセボ投与, 黒丸 ; リファンピン投与 

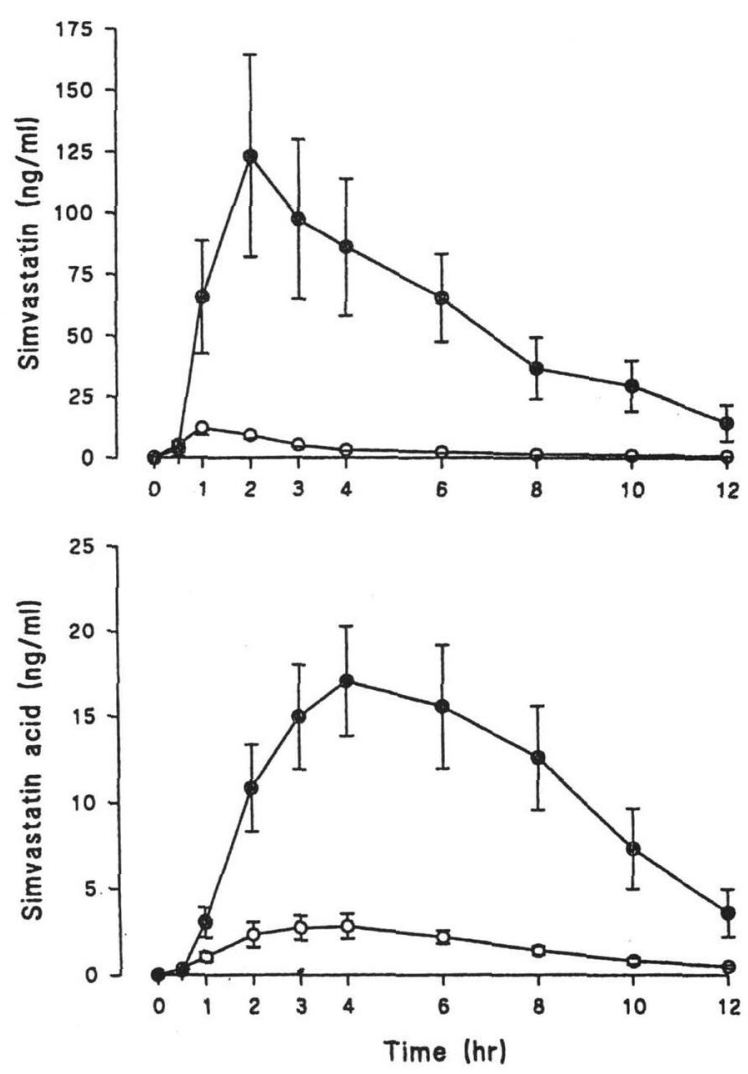

図 3 グレープフルーツシュースとシンバスタチンの相互作 用: シンバスタチン, シンバスタチン酸の血中濃度推 移13)

$200 \mathrm{~m} l$ のグレープフルーツジュースまたは水を 1 日 3 回 2 日間摂取し最終撕取 30 分後にシンバスタチン 60 $\mathrm{mg}$ を経口投与後の血中濃度. 白丸 ; 水, 黒丸 ; グレー プフルーツジュース摂取

表 1 リファンピン, リファブチンと経口避妊薬の相互作 用: 血中 LH, FSH レベルの変化

\begin{tabular}{|c|c|c|c|}
\hline & Rifampin & Rifabutin & $\begin{array}{l}\text { Rifampin } \\
\text { versus } \\
\text { rifabutin }\end{array}$ \\
\hline \multicolumn{4}{|c|}{ Luteinizing hormone $(\mathrm{mIU} / \mathrm{mL})$} \\
\hline Day 7 & $3.9 \pm 3.8$ & $3.8 \pm 3.0$ & \\
\hline Day 21 & $5.3 \pm 5.2$ & $2.2 \pm 2.1$ & \\
\hline Difference & $1.4 \pm 3.5$ & $-1.6 \pm 3.0$ & $2.9 \pm 5.2$ \\
\hline \multicolumn{4}{|c|}{ Follicle-stimulating hormone $(\mathrm{mIU} / \mathrm{mL})$} \\
\hline Day 7 & $2.9 \pm 2.1$ & $2.7 \pm 1.9$ & \\
\hline Day 21 & $4.9 \pm 3.5$ & $2.4 \pm 2.0$ & \\
\hline Difference & $2.0 \pm 2.0^{*}$ & $-0.3 \pm 0.8$ & $2.3 \pm 2.4^{*}$ \\
\hline
\end{tabular}

Data are mean values \pm SD.

${ }^{*} P<.01$.

FSH : $13.6 \mathrm{mIU} / \mathrm{mL})$ と比較すると明らかに低值である (表 16)）。つ屯り，この報告では併用投与によって血 中 LH, FSH に多少の上昇は認められたが, 併用期間中 も被験者の排卵は経口避妊薬によって抑制されていたの である. また経口避妊薬と抗真菌薬との併用投与でも経
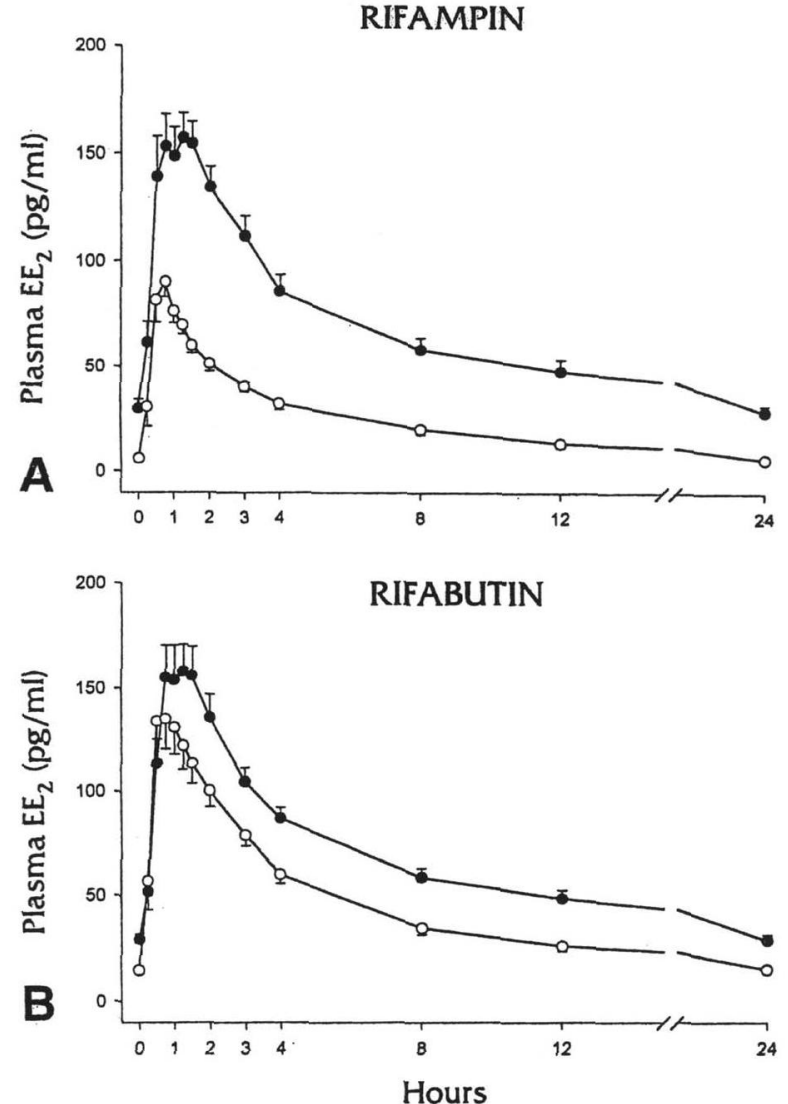

図 4 リファンピン, リファブチンと経口避妊薬の相互作用 : エチニールエストラダイオールの血中濃度推移16) 黒丸；リファンピン, リファブチン投与前, 白丸; 併用 後 14 日後. A : リファンピン併用, B : リファブチン 併用

口避妊薬の効果が減弱されたという科学的証明はな い17).つ屯りこのような場合，臨床的にはこれら卵巣 機能を示すホルモン濃度を測定することが薬効の検討に は大切である. しかし一般に望まれていない妊娠が人々 に深刻な状況を作り出すことも考慮すると，これらの薬 物と経口避妊薬との併用には十分な注意も必要であ る18).

\section{結論}

有害な薬物相互作用に関する情報を医療現場で臨床医 が望むような情報に改善していくために, 厚生省, 製薬 企業などが医薬品の添付文書を改善したり, 我が国の新 薬開発における薬物相互作用のガイダンスを作成するな どの努力がなされている.

新薬開発過程においてはヒトでの臨床試験に入る前の 非臨床試験で薬物相互作用の可能性が懸念されるものに ついては, その薬物が関与する肝薬物代謝酵素, 特にヒ トCYPの分子種を同定する必要がある.すでにこの分 野の検討は多くの開発品において行われているが，いず 
表 2 臨床医が知りたい有害作用情報

पHow to predict the ADR:
- Clinical Symptoms
- Laboratory Data
- Plasma Concentration
How to grade the ADR
How to qualify the ADR:
- Dose-related
- Reversible
How to treat the ARD
How to pursue the treatment

れにしても非臨床試験, in vitro 試験においては臨床試 験では検討できない毒性情報を多くの方面から検討すべ きであろう。

もし，この段階で有害作用の発現が明らかとなった場 合, その作用が可逆的か, 不可逆的か, またその有害作 用の発現を予測する具体的方法はあるのかを検討すべき である．このことは臨床的に有用な薬物を安全に使用す るために必要である.

特殊患者における薬物相互作用の検討も必要である が，特に小児患者で検討するためにはより侵襲性の少な い検査方法の確立が必要である. 最近, 小児でカルバマ ゼピンがカフェインの代謝を誘導することがカフェイン Breath Test で示された ${ }^{19)}$ が, このような非侵襲的で精 度の高い検査方法の開発も大切である.

臨床試験において重大な薬物相互作用が発現した場 合, 臨床的に最も大切な概念はその薬物の対象疾患にお ける臨床的有効性と安全性のバランスである. 他に代わ るうる薬物が存在したり, 生活習慣病のようなものを対 象とするような薬物であれば，その薬物の開発は中止す べきであらう。しかし, 多少の毒性は覚悟しても臨床的 に非常に有効な作用が期待できる薬物である場合, また その薬物に代わる有効な薬物がない疾患の場合には, 併 用投与を禁忌としたり，より低用量で毒性が減少し有効 性が維持できるかなどの用量設定を含めた臨床検討が必 要となる.

最後に臨床医にとって有用な薬物相互作用情報ををと めると表 2 のようになり, 具体的な有害作用の予測方法 (臨床症状, 臨床検査, 薬物血中濃度) は何か? また有 害作用の程度は重篤かどうか? 有害作用の質は用量に 相関したものか, 可逆的なものか？その有害作用の治 療法はあるのか？ 原疾患の治療法は他にあるのか？ などであることを繰り返し付け加えておく.

\section{文献}

1) Diasio RB: Sorivudine and 5-fluorouracil; A clinically sig- nificant drug-drug interaction due to inhibition of dihydropyrimidine dehydrogenase. $\mathrm{Br} J$ Clin Pharmacol 46(1): 1-4, (1998).

2) Okuda H, Ogura K, Kato A, Takubo H, Watabe T: A possible mechanism of eighteen patient deaths caused by interactions of sorivudine, a new antiviral drug, with oral 5fluorouracil prodrugs. J Pharmacol Exp Ther 287 (2) : 791-9 (1998).

3) Honig PK, Woosley RL, Zamani K, Conner DP, Cantilena LR Jr: Changes in the pharmacokinetics and electrocardiographic pharmacodynamics of terfenadine with concomitant administration of erythromycin. Clin Pharmacol Ther 52 (3): 231-8 (1992).

4) Piquette RK: Torsade de pointes induced by cisapride/ clarithromycin interaction. Ann Pharmacother 33 (1): 22-6 (1999).

5) Honig PK, Worham DC, Zamani K, Mullin JC, Conner DP, Cantilena LR: The effect of fluconazole on the steady-state pharmacokinetics and electrocardiographic pharmacodynamics of terfenadine in humans. Clin Pharmacol Ther 53(6): 630-6 (1993).

6) Honig PK, Wortham DC, Zamani K, Conner DP, Mullin JC, Cantilena LR: Effect of concomitant administration of cimetidine and ranitidine on the pharmacokinetics and electrocardiographic effects of terfenadine. Eur $J$ Clin Pharmacol 45(1): 41-6 (1993).

7) Burkhart GA, Sevka MJ, Temple R, Honig PK: Temporal decline in filling prescriptions for terfenadine closely in time with those for either ketoconazole or erythromycin. Clin Pharmacol Ther 61(1): 93-6 (1997).

8) Yamagata T, Momoi MY, Murai K, Ikematsu K, Suwa K, Sakamoto K, Fujimura A: Panipenem-betamipron and decreases in serum valproic acid concentration. Ther Drug Monit 20 (4): 396-400 (1998).

9) Nagai K, Shimizu T, Togo A, Takeya M, Yokomizo Y, Sakata Y, Matsuishi T, Kato H: Decrease in serum levels of valproic acid during treatment with a new carbapenem, panipenem/betamipron. J Antimicrob Chemother 39(2): 295-6 (1997).

10) Yamamura $N$, Imura $K$, Naganuma $H$, Nishimura $K$ : Panipenem, a carbapenem antibiotic, enhances the glucuronidation of intravenously administered valproic acid in rats. Drug Metab Dispos 27 (6): 724-30 (1999).

11) Kojima $S$, Nadai $M$, Kitaichi $K$, Wang $L$, Nabeshima $T$, Hasegawa T: Possible mechanism by which the carbapenem antibiotic panipenem decreases the concentration of valproic acid in plasma in rats. Antimicrob Agents Chemother 42(12): 3136-40 (1998).

12) Villikka K, Kivisto KT, Neuvonen PJ: The effect of rifampin on the pharmacokinetics of oral and intravenous ondansetron. Clin Pharmacol Ther 65 (4): 377-81 (1999).

13) Lilja JJ, Kivisto KT, Neuvonen PJ; Grapefruit juice-simvastatin interaction: Effect on serum concentrations of simvastatin, simvastatin acid, and HMG-CoA reductase inhibitors. Clin Pharmacol Ther 64(5): 477-83 (1998).

14) Ubeaud G, Hagenbach J, Vandenschrieck S, Jung L, Koffel JC: In vitro inhibition of simvastatin metabolism in rat and human liver by naringenin. Life Sci 65 (13): 140312 (1999).

15) Lilja JJ, Kivisto KT, Neuvonen PJ: Grapefruit juice increases serum concentrations of atorvastatin and has no effect on pravastatin. Clin Pharmacol Ther 66(2): 118-27 
(1999).

16) Barditch-Crovo P, Trapnell CB, Ette E, Zacur HA, Coresh J, Rocco LE, Hendrix CW, Flexner C: The effects of rifampin and rifabutin on the pharmacokinetics and pharmacodynamics of a combination oral contraceptive. Clin Pharmacol Ther 65 (4): 428-38 (1999).

17) Weisberg E: Interactions between oral contraceptives and antifungals/antibacterials. Is contraceptive failure the result? Clin Pharmacokinet 36(5): 309-13 (1999).

18) Clinical Effectiveness Committee: From the Clinical Effectiveness Committee. Use of rifampicin and contraceptive steroids. Br J Fam Plann 24 (4): 169-70 (1999).

19) Parker AC, Pritchard P, Preston T, Choonara I: Induction of CYP1A2 activity by carbamazepine in children using the caffeine breath test. Br J Clin Pharmacol 45 (2): 176-8 (1998). 